\title{
Compelling Evidence for the Activity of Antiviral Peptides against SARS-CoV-2
}

\author{
Miray Tonk ${ }^{1,2}$ (D), Daniel Růžek ${ }^{3,4}$ (D) and Andreas Vilcinskas $1,2,5, *$ (D) \\ 1 Institute for Insect Biotechnology, Justus Liebig University of Giessen, Heinrich-Buff-Ring 26-32, \\ 35392 Giessen, Germany; miray.tonk@agrar.uni-giesssen.de \\ 2 LOEWE Centre for Translational Biodiversity Genomics (LOEWE-TBG), Senckenberganlage 25, \\ 60325 Frankfurt, Germany \\ 3 Department of Virology, Veterinary Research Institute, Hudcova 70, CZ-62100 Brno, Czech Republic; \\ ruzekd@paru.cas.cz \\ 4 Biology Centre of the Czech Academy of Sciences, Institute of Parasitology, Branisovska 31, \\ 37005 Ceske Budejovice, Czech Republic \\ 5 Department of Bioresources, Fraunhofer Institute for Molecular Biology and Applied Ecology, \\ Ohlebergsweg 12, 35392 Giessen, Germany \\ * Correspondence: andreas.vilcinskas@agrar.uni-giesssen.de
}

check for updates

Citation: Tonk, M.; Růžek, D.;

Vilcinskas, A. Compelling Evidence for the Activity of Antiviral Peptides against SARS-CoV-2. Viruses 2021, 13, 912. https://doi.org/10.3390/ v13050912

Academic Editors: Jeroen van Kampen and Pieter L. A. Fraaij

Received: 7 April 2021

Accepted: 12 May 2021

Published: 14 May 2021

Publisher's Note: MDPI stays neutral with regard to jurisdictional claims in published maps and institutional affiliations.

Copyright: (c) 2021 by the authors. Licensee MDPI, Basel, Switzerland. This article is an open access article distributed under the terms and conditions of the Creative Commons Attribution (CC BY) license (https:/ / creativecommons.org/licenses/by/ $4.0 /)$.

\begin{abstract}
Multiple outbreaks of epidemic and pandemic viral diseases have occurred in the last 20 years, including those caused by Ebola virus, Zika virus, and severe acute respiratory syndrome coronavirus 2 (SARS-CoV-2). The emergence or re-emergence of such diseases has revealed the deficiency in our pipeline for the discovery and development of antiviral drugs. One promising solution is the extensive library of antimicrobial peptides (AMPs) produced by all eukaryotic organisms. AMPs are widely known for their activity against bacteria, but many possess additional antifungal, antiparasitic, insecticidal, anticancer, or antiviral activities. AMPs could therefore be suitable as leads for the development of new peptide-based antiviral drugs. Sixty therapeutic peptides had been approved by the end of 2018, with at least another 150 in preclinical or clinical development. Peptides undergoing clinical trials include analogs, mimetics, and natural AMPs. The advantages of AMPs include novel mechanisms of action that hinder the evolution of resistance, low molecular weight, low toxicity toward human cells but high specificity and efficacy, the latter enhanced by the optimization of AMP sequences. In this opinion article, we summarize the evidence supporting the efficacy of antiviral AMPs and discuss their potential to treat emerging viral diseases including COVID-19.
\end{abstract}

Keywords: SARS-CoV-2; COVID-19; coronavirus; antimicrobial peptides; antiviral peptides; defensins

\section{Introduction \\ 1.1. SARS-CoV-2 and the Role of Antiviral Therapy Including AMPS}

Severe acute respiratory syndrome coronavirus 2 (SARS-CoV-2) is a $\beta$-coronavirus that emerged in late 2019 from the Wuhan region of China [1-3]. SARS-CoV-2 is the agent responsible for coronavirus disease 2019 (COVID-19), which was declared a pandemic by the World Health Organization (WHO) on 11 March 2020 and has thus far caused more than 2.8 million deaths worldwide along with significant socioeconomic disruption $[4,5]$. Most people infected by SARS-CoV-2 are asymptomatic but still capable of transmission. Others show symptoms such as fever, cough and fatigue, ranging from mild to severe, which may last days or weeks. In the worst cases, the virus induces a cytokine storm that damages the lungs and leaves patients exposed to potentially fatal pneumonia [6,7].

Although vaccines confer protection against viruses before exposure, antiviral drugs are the first line of defense when people are already infected. However, a specific antiviral with high efficacy against SARS-CoV-2 is not yet available [8]. General antiviral drugs 
such as remdesivir, lopinavir/ritonavir, and umifenovir are already used, but their effectiveness is limited by the need to treat patients before the peak of viral replication $[8,9]$. Ribavirin may be favorable as an adjunct therapy but is not effective when administered alone $[8,10]$. Corticosteroids reduce mortality associated with severe COVID-19 symptoms but increase mortality in patients with coronavirus-associated pneumonia [11,12]. Intravenous immunoglobulin (IVIG) is not recommended for COVID-19 patients because there is insufficient supporting data [13]. Chloroquine and hydroxychloroquine can inhibit the replication of SARS-CoV-2 in cell lines but their clinical efficacy is unclear, especially in terms of whether the benefits outweigh the risk of dysrhythmias [14]. Interleukin-6 receptor antagonists may be beneficial in patients with cytokine release syndrome, although the effectiveness is not yet clear [15-18]. Cocktails of potent monoclonal antibodies targeting viral spike protein are effective for the treatment and prophylaxis of COVID-19, but their use is limited by the high costs of antibody production [19].

The success of antiviral therapy is dependent on many factors, including the rate of virus mutation, the genetic diversity of the viral population, the transmission route, the efficiency of viral replication, and viral persistence in the host [20]. Viruses that replicate quickly and with a greater mutation frequency can overcome antiviral drugs, so the development pipeline must be filled with new drug candidates, preferably with novel mechanisms of action [21]. There is already evidence that SARS-CoV-2 is diversifying into new lineages that are resistant to current antiviral drugs [22-24]. Antimicrobial peptides (AMPs) are one of the most promising categories of new antiviral drug candidates because many of them are active against viruses as well as other pathogens.

AMPs are cationic peptides (net positive charge) with amphipathic characteristics (hydrophobic and hydrophilic regions) that are essential for their activity $[25,26]$. They can be assigned to four categories based on their structure [27]: linear $\alpha$-helical peptides, $\beta$-sheet peptides, linear extension structures, and mixed $\alpha$-helix and $\beta$-sheet peptides (Figure 1). Natural AMPs offer a rich source of novel antiviral agents, and additional diversity can be achieved by designing synthetic AMPs that mimic the ability of natural peptides to block critical steps in the viral life cycle [28]. The antiviral mode of action varies, but may include the direct inhibition of viral particles, competition for host cell receptors, inhibition of interactions and blocking of adsorption [29]. Some AMPs also suppress viral gene expression [30,31].

AMPs are produced naturally by all eukaryotic organisms but the analysis of AMP sequences has also facilitated the production of small molecules with similar structures (peptidomimetics) that capture the biological function of AMPs while enhancing their activity and/or reducing off-target effects [22]. AMPs offer a solution to the challenge of drug resistance because the sequences of individual AMPs can be altered very easily to keep pace with viral mutations, and two or more AMPs can be used together, or in combination with conventional treatments, to further reduce the likelihood of viral escape mutants and to exploit any additive or synergistic effects [23]. Many AMPs also have immunostimulatory properties that enhance natural innate immunity. AMPs therefore provide a new route to combination therapies involving antiviral peptides and other drugs with diverse mechanisms of action.

\subsection{Defensins as Antiviral AMPs}

Defensins are components of the innate immune system and are active against diverse pathogens [24,32]. They are cationic, amphipathic peptides, 29-42 amino acids in length, with a predominantly $\beta$-sheet structure stabilized by three disulfide bonds [32]. Their promising antiviral effects $[33,34]$ are based on several distinct mechanisms of action, including interactions with anionic phospholipids to disrupt lipid bilayers [35] or direct binding to glycoproteins and glycolipids [36]. This aligns with the goal of researchers to find antiviral drugs that act directly against viral functions (replication, gene expression, and/or protein processing) or block viral attachment and fusion by interacting with viral proteins or their receptors on host cells [21,37-39]. 

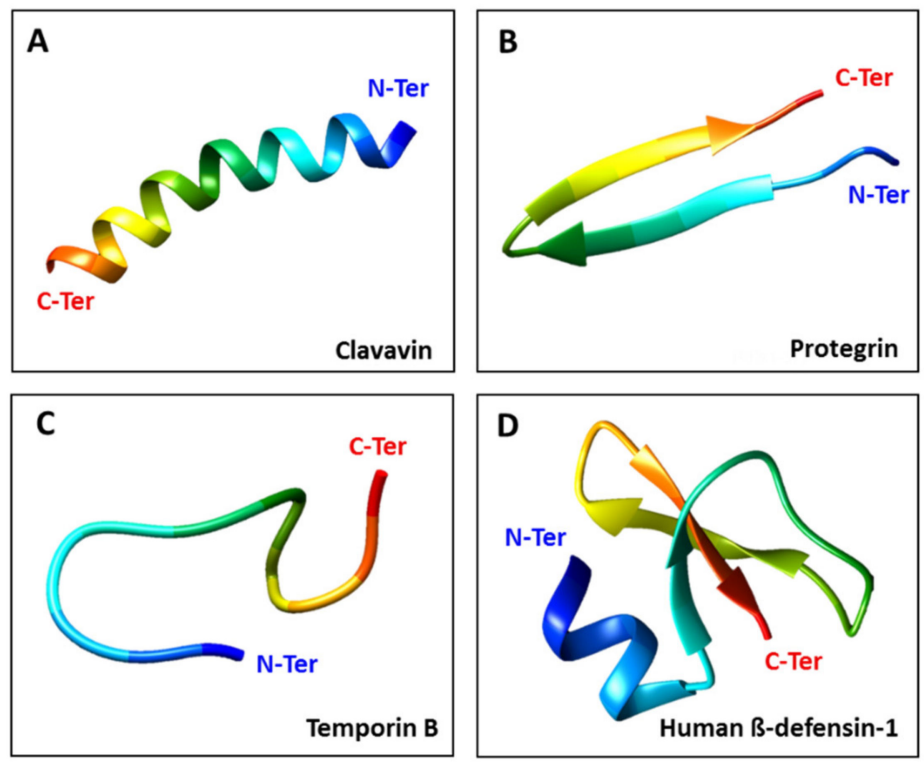

Figure 1. The four main structural classes of AMPs. (A) Clavavin adopts a typical $\alpha$-helical conformation $(10.2210 /$ pdb6C41/pdb). (B) Protegrin PG-5 is a $\beta$-sheet peptide $(10.2210 / \mathrm{pdb} 2 \mathrm{NC} 7 / \mathrm{pdb})$. (C) Temporin B has a linear extension structure (10.2210/pdb6GIL/pdb). (D) Human $\beta$-defensin 1 features both $\alpha$-helix and $\beta$-sheet structures $(10.2210 / \mathrm{pdb} 1 \mathrm{IJV} / \mathrm{pdb})$. The antiviral peptides were obtained from the Protein Data Bank (PDB) and adjustments were made using UCSF Chimera (http:/ / www.cgl.ucsf.edu/chimera accessed on 22 April 2021).

The first study reporting the in vitro antiviral activity of cationic AMPs involved human granulocyte defensins [40], which were shown to inhibit herpes simplex virus (HSV) types 1 and 2 and cytomegalovirus (CMV), as well as human neutrophil peptide 1 (HNP1), which inhibited vesicular stomatitis virus (VSV) [40,41]. Other defensins have been shown to confer protection against severe acute respiratory syndrome coronavirus (SARS-CoV), human immunodeficiency virus (HIV), influenza A virus, human adenovirus, human papillomavirus (HPV), HSV, and respiratory syncytial virus (RSV) [32,39,42,43]. Recently, the potent antiviral activity of defensin-like peptide P9R was demonstrated against multiple enveloped viruses that require endosomal acidification, including SARS$\mathrm{CoV}$, SARS-CoV-2, Middle East respiratory syndrome coronavirus (MERS-CoV), influenza A virus H1N1pdm09 (responsible for the 2009 pandemic of swine flu), avian influenza A virus H7N9, and also the non-enveloped rhinovirus (Table 1) [44]. P9, the parental peptide of P9R, which is derived from mouse $\beta$-defensin 4 , also showed activity against SARS-CoV-2, MERS-CoV, and influenza viruses by binding to the viral glycoprotein and inhibiting endosomal acidification (Figure 2) [44,45]. Short P9 derivatives joined to the HIV Tat protein were able to deliver defective interfering influenzavirus genes that prevent endosomal acidification in vitro and in vivo [45]. Another study showed the antiviral effect of defensins against Zika virus by interacting with the surface protein and disrupting the integrity of the viral membrane [46], and against MERS-CoV by acting as a fusion inhibitor [47]. The $\theta$-defensin retrocylin 2 (RC 2) shows activity against many viruses, including influenza virus and HSV, and a scorpion venom peptide variant (mucroporin-M1) is able to inhibit measles virus, SARS-CoV and influenza A virus H5N1 [48]. Enfuvirtide (Fuzeon or T-20) was the first antiviral peptide approved for the treatment of HIV [49] and others were approved subsequently [50]. Recently, the defensin-mimetic Brilacidin, a peptidomimetic synthetic small molecule, was shown to inhibit SARS-CoV-2 in a human lung cell line expressing ACE2 by disrupting the virus and blocking entry into cells [22]. Brilacidin together with remdesivir also showed synergistic activity against SARS-CoV-2 in vitro [22]. 


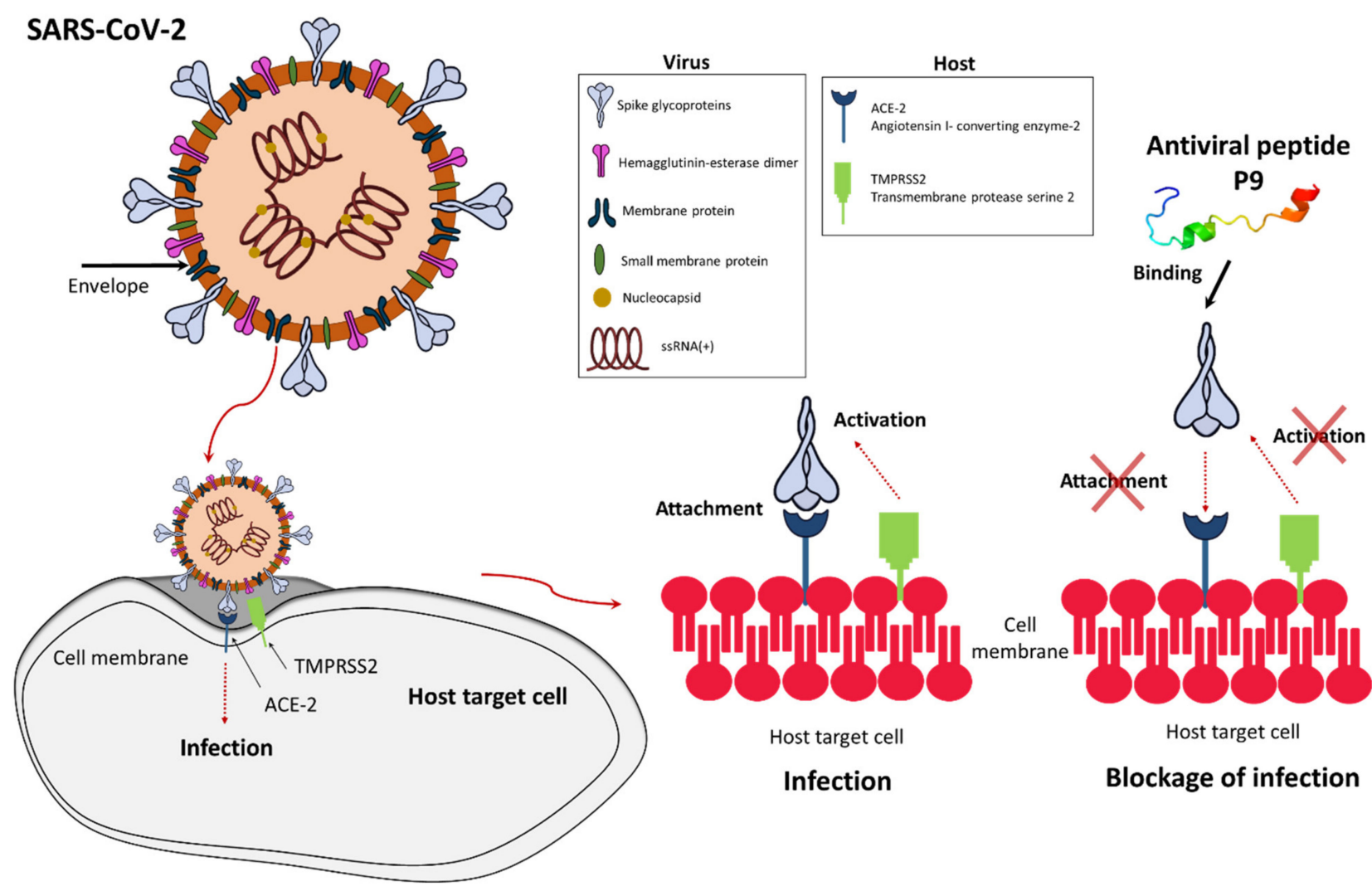

Figure 2. Inhibition of SARS-CoV-2 infection by antiviral peptide P9. In a normal infection, the SARS-CoV-2 spike glycoprotein binds to host cell receptor ACE-2, allowing fusion with the host cell membrane. Antiviral peptide P9 binds to the surface of the spike glycoprotein and blocks its access to ACE-2, thus preventing fusion. The secondary structure of P9 was predicted using the Phyre2 protein modeling program [51].

Several modes of action can be deployed by AMPs to inhibit the replication of SARS$\mathrm{CoV}-2$. Some AMPs exert a direct virucidal effect by targeting the viral envelope, as seen for mucroporin-M1 and brilacidin [22,48]. Others bind to the viral spike glycoprotein, thus preventing its interaction with ACE2 on host cells [52,53]. Defensin-like peptide P9R and its parental peptide P9 prevent endosomal acidification, which is necessary for uncoating during the early stages of the viral life cycle [44,54]. In addition, a natural lectin-like human intestinal defensin 5 (HD5) can shield the ACE2, preventing SARS-CoV-2 binding [55]. Finally, the indirect immunomodulatory activity of AMPs may help to reduce the severity of COVID-19 symptoms [56].

\subsection{Other Natural AMPs with Antiviral Properties}

In addition to defensins, other AMPs have also demonstrated antiviral activity. The $\mathrm{K} \alpha 2$-helix peptide derived from the viral FLICE-like inhibitor protein of human gammaherspesvirus 8 (HHV-8) showed activity against influenza A virus in vitro and in vivo [71]. When $K \alpha 2$ was joined to the HIV Tat peptide, the hybrid Tat-K $\alpha 2$ significantly inhibited influenza A virus replication and transmission, and protected mice challenged with lethal doses of the highly pathogenic H5N1 and H1N1 strains [71]. The Tat-K $\alpha 2$ peptide was shown to destabilize viral membranes, depending on the lipid composition of the viral envelope [59]. K $\alpha 2$ also inhibited infections with enveloped viruses such as VSV and RSV but with negligible cytotoxicity [59]. The antiviral peptide urumin from a south Indian frog was also active against influenza A virus strains that are resistant to oseltamivir, zanamivir, and peramivir [68]. 
Table 1. Antimicrobial peptides with antiviral properties.

\begin{tabular}{|c|c|c|c|c|c|c|c|}
\hline Antiviral Peptides & Source & Group & Sequence & Activity & Type & Mechanism of Action & Reference \\
\hline $\begin{array}{c}\text { P9R ( } \beta \text {-defensin-4 } \\
\text { derivative) }\end{array}$ & Mus musculus & Mouse & $\begin{array}{l}\text { NGAICWGPC } \\
\text { PTAFRQIGNC } \\
\text { GRFRVRCCRIR }\end{array}$ & $\begin{array}{l}\text { SARS-CoV-2, MERS-CoV, } \\
\text { SARS-CoV, } \\
\text { A(H1N1)pdm09, } \\
\text { A(H7N9) virus, and the } \\
\text { non-enveloped } \\
\text { rhinovirus }\end{array}$ & $\begin{array}{l}\text { RNA, } \\
\text { Enveloped/Non- } \\
\text { enveloped }\end{array}$ & $\begin{array}{l}\text { Inhibits viral replication by } \\
\text { binding to different viruses and } \\
\text { then inhibits virus-host } \\
\text { endosomal acidification to } \\
\text { prevent the endosomal release } \\
\text { of pH-dependent viruses }\end{array}$ & [44] \\
\hline P9 ( $\beta$-defensin-4) & Mus musculus & Mouse & $\begin{array}{l}\text { NGAICWGPCP } \\
\text { TAFRQIGNCG } \\
\text { HFKVRCCKIR }\end{array}$ & $\begin{array}{l}\text { SARS-CoV, MERS-CoV, } \\
\text { IAV (H1N1, H3N2, } \\
\text { H5N1, H7N7, H7N9) }\end{array}$ & RNA, Enveloped & $\begin{array}{l}\text { High-affinity binding to viral } \\
\text { glycoproteins }\end{array}$ & {$[54]$} \\
\hline$\theta$-defensin retrocylin 2 & Synthetic construct & ND & $\begin{array}{l}\text { GICRCICGR } \\
\text { RICRCICGR }\end{array}$ & $\begin{array}{l}\text { HIV, HSV, Influenza } \\
\text { virus, Sindbis virus, } \\
\text { Baculovirus }\end{array}$ & $\begin{array}{c}\text { RNA, } \\
\text { Enveloped/DNA } \\
\text { virus }\end{array}$ & $\begin{array}{l}\text { Inhibits viral fusion and entry } \\
\text { by crosslinking membrane } \\
\text { glycoproteins }\end{array}$ & {$[36,57]$} \\
\hline $\begin{array}{l}\text { MP7-NH2 (Mastoparan } \\
\text { derivative) }\end{array}$ & Vespula lewisii & Insect & INLKALAALAKALL & VSV & RNA, Enveloped & $\begin{array}{l}\text { Interact with the lipid } \\
\text { component of virus membranes } \\
\text { and thereby reduce infectivity of } \\
\text { enveloped viruses }\end{array}$ & [58] \\
\hline longicin P4 & $\begin{array}{c}\text { Haemaphysalis } \\
\text { longicornis }\end{array}$ & Tick & $\begin{array}{c}\text { SIGRRGGY } \\
\text { CAGIIKQTCTCYR }\end{array}$ & TBEV surrogate LGTV & RNA, Enveloped & ND & {$[60]$} \\
\hline Mucroporin-M1 & Lychas mucronatus & Scorpion & LFRLIKSLIKRLVSAFK & $\begin{array}{l}\text { SARS-CoV, H5N1, } \\
\text { Measles virus }\end{array}$ & RNA, Enveloped & Virus envelope interaction & [48] \\
\hline
\end{tabular}


Table 1. Cont

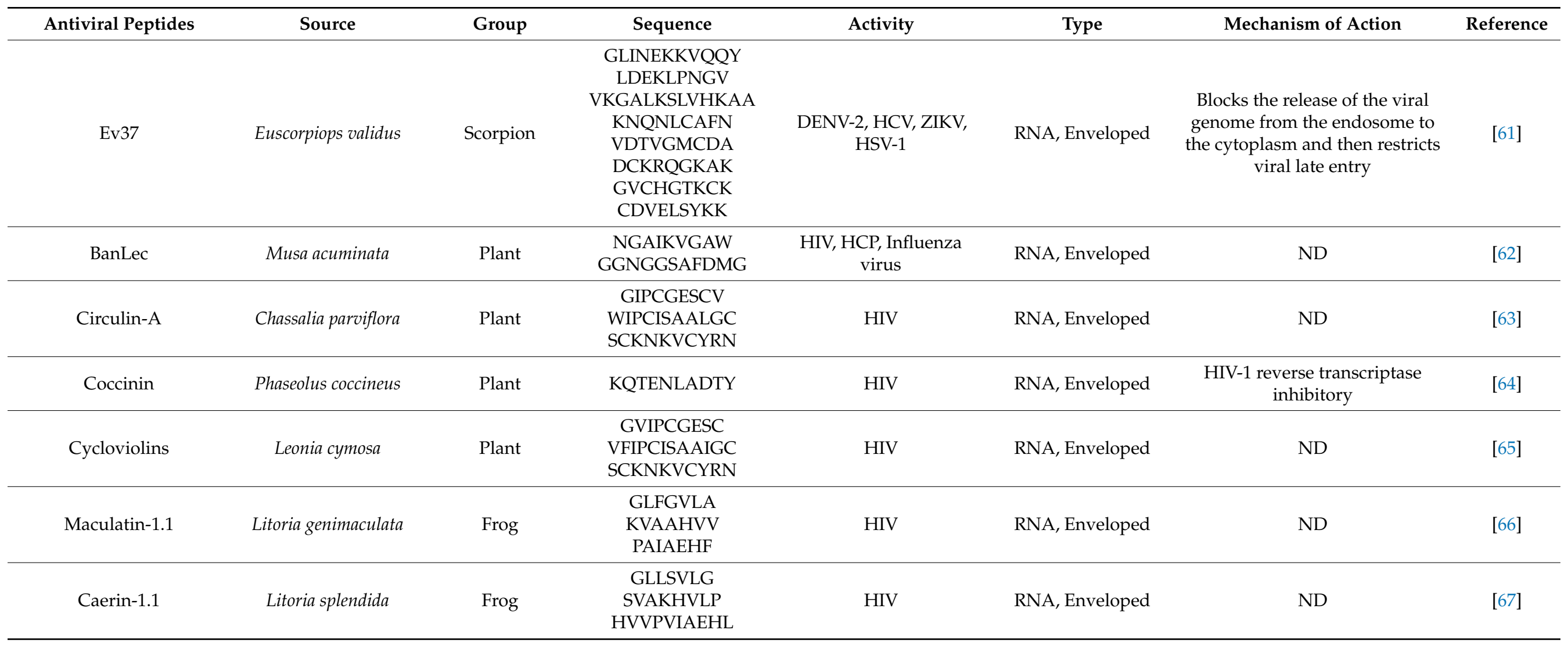


Table 1. Cont.

\begin{tabular}{|c|c|c|c|c|c|c|c|}
\hline Antiviral Peptides & Source & Group & Sequence & Activity & Type & Mechanism of Action & Reference \\
\hline Urumin & $\begin{array}{l}\text { Hydrophylax } \\
\text { bahuvistara }\end{array}$ & Frog & $\begin{array}{c}\text { IPLRGAFI } \\
\text { NGRWDS } \\
\text { QCHRFSNGAIACA }\end{array}$ & $\begin{array}{l}\mathrm{H} 1 \\
\text { hemagglutinin-bearing } \\
\text { human IAV }\end{array}$ & RNA, Enveloped & $\begin{array}{l}\text { Destroys virions, targets the } \\
\text { hemagglutinin stalk region }\end{array}$ & [68] \\
\hline Tachyplesin I & Tachypleus tridentatus & Horseshoe crab & $\begin{array}{l}\text { KWCFRV } \\
\text { CYRGIC } \\
\text { YRRCR }\end{array}$ & VSV, IAV H1N1 & RNA, Enveloped & $\begin{array}{l}\text { Inactivates the VSV by } \\
\text { destroying its envelope subunits }\end{array}$ & [69] \\
\hline Cyanovirin-N & Nostoc ellipsosporum & Cyanobacterium & $\begin{array}{c}\text { LGKFSQTC } \\
\text { YNSAIQGSV } \\
\text { LTSTCERTNGG } \\
\text { YNTSSIDLNS } \\
\text { VIENVDGSLKW } \\
\text { QPSNFIETCRNT } \\
\text { QLAGSSELAAECK } \\
\text { TRAQQFVSTKIN } \\
\text { LDDHIANIDGTLKYE }\end{array}$ & HIV-1 & RNA, Enveloped & $\begin{array}{l}\text { Binds viral surface envelope } \\
\text { glycoprotein gp120 }\end{array}$ & [70] \\
\hline
\end{tabular}

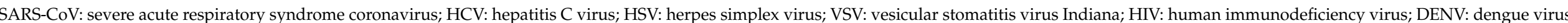
type 2; ZIKV: Zika virus; IAV: influenza A virus; TBEV: tick-borne encephalitis virus; LGTV: Langat virus; H1N1: influenza A virus subtype H1N1. 
The AMP database DRAMP currently lists 2015 antiviral AMPs from diverse origins [62], which will facilitate the identification of antiviral candidates that inhibit the virus infection cycle either by directly blocking functions such as replication or by obstructing virus-host interactions or trafficking. In the latter case, antiviral peptides that block the endosomal acidification of $\mathrm{pH}$-dependent viruses are promising because this includes many of the highly pathogenic viruses that have emerged in recent years [68].

\subsection{Advantages and Disadvantages of AMPs}

Antiviral drug resistance is a public health concern because resistant mutants can spread rapidly to become predominant in the population [72,73]. The emergence of avian influenza A(H1N1)pdm09 mutants resistant to the AMP P9R and the approved antiviral drug zanamivir has been compared, revealing that resistance to zanamivir emerged after 10 passages in the presence of the drug whereas no resistance to P9R was observed even after 40 passages [44].

Other advantages of AMPs include the ability to produce new AMPs rapidly, and the high therapeutic ratio of many AMPs, combining high efficacy with low toxicity in humans [74-76]. It is therefore possible to achieve high specificity and effectiveness at low concentrations with minimal side effects [77-80]. For example, the Zika virus inhibitor Z2 showed low toxicity in vitro and in vivo in pregnant mice and fetuses, which suggests the drugs could be safe for use by pregnant women [46].

Conversely, the drawbacks of AMPs include their short half-life and high costs of production $[27,29,81]$. The former can be addressed by using amino acid D-enantiomers, which are less susceptible to proteolytic enzymes while maintaining antiviral activity [82]. Cost reductions can be achieved by optimizing the AMP synthesis and purification methods, including the replacement of chemical synthesis with the production of recombinant peptides in host cells that are not susceptible to the specific AMP product [83].

AMPs have low immunogenicity [84] and they can be also used in combination with other drugs to enhance their efficacy at lower concentrations [27]. Cocktail therapies based on combinations of natural and/or synthetic AMPs or other antiviral agents could also be tested for the treatment of COVID-19 [56]. However, more studies are needed to confirm the effectiveness and safety of such approaches, particularly in the case of pregnant women and immunocompromised patients.

\section{Conclusions}

Emerging and re-emerging viruses have caused severe socioeconomic disruption over the last two decades, reminding us that we are still unprepared to deal with viral pandemics. This reflects the lack of effective antivirals, removing an essential front line treatment option and making us reliant on vaccination to avoid significant morbidity and mortality. In this opinion article, we have highlighted the potential of AMPs as candidate antiviral drugs or drug leads. AMPs can be produced rapidly by chemical synthesis or the expression of recombinant peptides, and can be modified to improve their efficacy and stability in vivo. AMPs could therefore be used in the fight against COVID-19 and future viral pandemics either as new first-line treatments or as adjuncts to existing antiviral drugs. Given the broad and potent activities of AMPs against multiple viruses, we recommend the funding of research into the development of AMPs as a new therapeutic strategy against viral diseases.

Author Contributions: Conceptualization; writing—original draft preparation, M.T.; review and editing, M.T., D.R., A.V. All authors have read and agreed to the published version of the manuscript.

Funding: M.T. and A.V. would like to acknowledge generous funding from the HMWK via the LOEWE Centre for Translational Biodiversity Genomics (LOEWE-TBG). D.R. was supported by the Czech Ministry of Health (grant No. NV19-05-00457).

Acknowledgments: The authors thank Richard M. Twyman for editing the manuscript. 
Conflicts of Interest: The authors declare no conflict of interest.

\section{References}

1. Fu, L.; Wang, B.; Yuan, T.; Chen, X.; Ao, Y.; Fitzpatrick, T.; Li, P.; Zhou, Y.; Lin, Y.; Duan, Q.; et al. Clinical Characteristics of Coronavirus Disease 2019 (COVID-19) in China: A Systematic Review and Meta-Analysis. J. Infect. 2020, 80, 656-665. [CrossRef] [PubMed]

2. Zhu, N.; Zhang, D.; Wang, W.; Li, X.; Yang, B.; Song, J.; Zhao, X.; Huang, B.; Shi, W.; Lu, R.; et al. A Novel Coronavirus from Patients with Pneumonia in China, 2019. N. Engl. J. Med. 2020, 382, 727-733. [CrossRef]

3. Khan, S.; Siddique, R.; Shereen, M.A.; Ali, A.; Liu, J.; Bai, Q.; Bashir, N.; Xue, M. Emergence of a Novel Coronavirus, Severe Acute Respiratory Syndrome Coronavirus 2: Biology and Therapeutic Options. J. Clin. Microbiol. 2020, 58. [CrossRef]

4. WHO. Coronavirus (COVID-19) Dashboard. Available online: https:/ / covid19.who.int/ (accessed on 30 March 2021).

5. COVID-19 Dashboard by the Center for Systems Science and Engineering (CSSE) at Johns Hopkins University (JHU). Available online: https: / / coronavirus.jhu.edu/map.html (accessed on 30 March 2021).

6. Su, L.; Ma, X.; Yu, H.; Zhang, Z.; Bian, P.; Han, Y.; Sun, J.; Liu, Y.; Yang, C.; Geng, J.; et al. The Different Clinical Characteristics of Corona Virus Disease Cases between Children and Their Families in China-The Character of Children with COVID-19. Emerg. Microbes Infect. 2020, 9, 707-713. [CrossRef]

7. Li, Y.-D.; Chi, W.-Y.; Su, J.-H.; Ferrall, L.; Hung, C.-F.; Wu, T.-C. Coronavirus Vaccine Development: From SARS and MERS to COVID-19. J. Biomed. Sci. 2020, 27, 104. [CrossRef]

8. Song, Y.; Zhang, M.; Yin, L.; Wang, K.; Zhou, Y.; Zhou, M.; Lu, Y. COVID-19 Treatment: Close to a Cure? A Rapid Review of Pharmacotherapies for the Novel Coronavirus (SARS-CoV-2). Int. J. Antimicrob. Agents 2020, 56, 106080. [CrossRef] [PubMed]

9. Eastman, R.T.; Roth, J.S.; Brimacombe, K.R.; Simeonov, A.; Shen, M.; Patnaik, S.; Hall, M.D. Remdesivir: A Review of Its Discovery and Development Leading to Emergency Use Authorization for Treatment of COVID-19. ACS Cent. Sci. 2020. [CrossRef]

10. Khalili, J.S.; Zhu, H.; Mak, N.S.A.; Yan, Y.; Zhu, Y. Novel Coronavirus Treatment with Ribavirin: Groundwork for an Evaluation Concerning COVID-19. J. Med. Virol. 2020, 92, 740-746. [CrossRef] [PubMed]

11. Arabi, Y.M.; Chrousos, G.P.; Meduri, G.U. The Ten Reasons Why Corticosteroid Therapy Reduces Mortality in Severe COVID-19. Intensive Care Med. 2020, 46, 2067-2070. [CrossRef]

12. Yang, Z.; Liu, J.; Zhou, Y.; Zhao, X.; Zhao, Q.; Liu, J. The Effect of Corticosteroid Treatment on Patients with Coronavirus Infection: A Systematic Review and Meta-Analysis. J. Infect. 2020, 81, e13-e20. [CrossRef]

13. Galeotti, C.; Kaveri, S.V.; Bayry, J. Intravenous Immunoglobulin Immunotherapy for Coronavirus Disease-19 (COVID-19). Clin. Transl. Immunol. 2020, 9, e1198. [CrossRef]

14. Oren, O.; Yang, E.H.; Gluckman, T.J.; Michos, E.D.; Blumenthal, R.S.; Gersh, B.J. Use of Chloroquine and Hydroxychloroquine in COVID-19 and Cardiovascular Implications. Circ. Arrhythm. Electrophysiol. 2020, 13, e008688. [CrossRef]

15. Guillén, L.; Padilla, S.; Fernández, M.; Agulló, V.; García, J.A.; Telenti, G.; García-Abellán, J.; Botella, Á.; Gutiérrez, F.; Masiá, M. Preemptive Interleukin-6 Blockade in Patients with COVID-19. Sci. Rep. 2020, 10, 16826. [CrossRef] [PubMed]

16. Nasonov, E.; Samsonov, M. The Role of Interleukin 6 Inhibitors in Therapy of Severe COVID-19. Biomed. Pharmacother. 2020, 131, 110698. [CrossRef] [PubMed]

17. Sinha, P.; Mostaghim, A.; Bielick, C.G.; McLaughlin, A.; Hamer, D.H.; Wetzler, L.M.; Bhadelia, N.; Fagan, M.A.; Linas, B.P.; Assoumou, S.A.; et al. Early Administration of Interleukin-6 Inhibitors for Patients with Severe COVID-19 Disease Is Associated with Decreased Intubation, Reduced Mortality, and Increased Discharge. Int. J. Infect. Dis. IJID 2020, 99, 28-33. [CrossRef] [PubMed]

18. Zhang, C.; Wu, Z.; Li, J.-W.; Zhao, H.; Wang, G.-Q. Cytokine Release Syndrome in Severe COVID-19: Interleukin-6 Receptor Antagonist Tocilizumab May Be the Key to Reduce Mortality. Int. J. Antimicrob. Agents 2020, 55, 105954. [CrossRef] [PubMed]

19. Jaworski, J.P. Neutralizing Monoclonal Antibodies for COVID-19 Treatment and Prevention. Biomed. J. 2021, 44, 7-17. [CrossRef]

20. Wagner, E.; Hewlett, M. WW I Retrovirus. In Basic Virology, 3rd ed.; Blackwell: Oxford, UK, 1999.

21. Lou, Z.; Sun, Y.; Rao, Z. Current Progress in Antiviral Strategies. Trends Pharmacol. Sci. 2014, 35, 86-102. [CrossRef]

22. Bakovic, A.; Risner, K.; Bhalla, N.; Alem, F.; Chang, T.L.; Weston, W.; Harness, J.A.; Narayanan, A. Brilacidin, a COVID-19 Drug Candidate, Exhibits Potent In Vitro Antiviral Activity Against SARS-CoV-2. bioRxiv 2020. [CrossRef]

23. Elnagdy, S.; AlKhazindar, M. The Potential of Antimicrobial Peptides as an Antiviral Therapy against COVID-19. ACS Pharmacol. Transl. Sci. 2020. [CrossRef]

24. Zhao, L.; Lu, W. Defensins in Innate Immunity. Curr. Opin. Hematol. 2014, 21, 37-42. [CrossRef] [PubMed]

25. Bulet, P.; Stöcklin, R.; Menin, L. Anti-Microbial Peptides: From Invertebrates to Vertebrates. Immunol. Rev. 2004, 198, 169-184. [CrossRef]

26. Jenssen, H.; Hamill, P.; Hancock, R.E.W. Peptide Antimicrobial Agents. Clin. Microbiol. Rev. 2006, 19, 491-511. [CrossRef] [PubMed]

27. Lei, J.; Sun, L.; Huang, S.; Zhu, C.; Li, P.; He, J.; Mackey, V.; Coy, D.H.; He, Q. The Antimicrobial Peptides and Their Potential Clinical Applications. Am. J. Transl. Res. 2019, 11, 3919-3931.

28. De Vries, R.D.; Schmitz, K.S.; Bovier, F.T.; Predella, C.; Khao, J.; Noack, D.; Haagmans, B.L.; Herfst, S.; Stearns, K.N.; Drew-Bear, J.; et al. Intranasal Fusion Inhibitory Lipopeptide Prevents Direct-Contact SARS-CoV-2 Transmission in Ferrets. Science 2021, 371, 1379-1382. [CrossRef] 
29. Galdiero, S.; Falanga, A.; Tarallo, R.; Russo, L.; Galdiero, E.; Cantisani, M.; Morelli, G.; Galdiero, M. Peptide Inhibitors against Herpes Simplex Virus Infections. J. Pept. Sci. 2013, 19, 148-158. [CrossRef]

30. Qureshi, A.; Thakur, N.; Kumar, M. VIRsiRNApred: A Web Server for Predicting Inhibition Efficacy of SiRNAs Targeting Human Viruses. J. Transl. Med. 2013, 11, 305. [CrossRef] [PubMed]

31. Zapata, W.; Aguilar-Jiménez, W.; Feng, Z.; Weinberg, A.; Russo, A.; Potenza, N.; Estrada, H.; Rugeles, M.T. Identification of Innate Immune Antiretroviral Factors during in Vivo and in Vitro Exposure to HIV-1. Microbes Infect. 2016, 18, 211-219. [CrossRef] [PubMed]

32. Wilson, S.S.; Wiens, M.E.; Smith, J.G. Antiviral Mechanisms of Human Defensins. J. Mol. Biol. 2013, 425, 4965-4980. [CrossRef] [PubMed]

33. Hazrati, E.; Galen, B.; Lu, W.; Wang, W.; Ouyang, Y.; Keller, M.J.; Lehrer, R.I.; Herold, B.C. Human Alpha- and Beta-Defensins Block Multiple Steps in Herpes Simplex Virus Infection. J. Immunol. 2006, 177, 8658-8666. [CrossRef]

34. Demirkhanyan, L.H.; Marin, M.; Padilla-Parra, S.; Zhan, C.; Miyauchi, K.; Jean-Baptiste, M.; Novitskiy, G.; Lu, W.; Melikyan, G.B. Multifaceted Mechanisms of HIV-1 Entry Inhibition by Human $\alpha$-Defensin. J. Biol. Chem. 2012, 287, 28821-28838. [CrossRef] [PubMed]

35. Wimley, W.C. Describing the Mechanism of Antimicrobial Peptide Action with the Interfacial Activity Model. ACS Chem. Biol. 2010, 5, 905-917. [CrossRef] [PubMed]

36. Leikina, E.; Delanoe-Ayari, H.; Melikov, K.; Cho, M.-S.; Chen, A.; Waring, A.J.; Wang, W.; Xie, Y.; Loo, J.A.; Lehrer, R.I.; et al. Carbohydrate-Binding Molecules Inhibit Viral Fusion and Entry by Crosslinking Membrane Glycoproteins. Nat. Immunol. 2005, 6, 995-1001. [CrossRef] [PubMed]

37. De Clercq, E. Antivirals: Past, Present and Future. Biochem. Pharmacol. 2013, 85, 727-744. [CrossRef] [PubMed]

38. Ison, M.G. Antiviral Treatments. Clin. Chest Med. 2017, 38, 139-153. [CrossRef]

39. Mulder, K.C.L.; Lima, L.A.; Miranda, V.J.; Dias, S.C.; Franco, O.L. Current Scenario of Peptide-Based Drugs: The Key Roles of Cationic Antitumor and Antiviral Peptides. Front. Microbiol. 2013, 4, 321. [CrossRef]

40. Daher, K.A.; Selsted, M.E.; Lehrer, R.I. Direct Inactivation of Viruses by Human Granulocyte Defensins. J. Virol. 1986, 60, 1068-1074. [CrossRef]

41. Gwyer Findlay, E.; Currie, S.M.; Davidson, D.J. Cationic Host Defence Peptides: Potential as Antiviral Therapeutics. BioDrugs Clin. Immunother. Biopharm. Gene Ther. 2013, 27, 479-493. [CrossRef]

42. Jiang, Y.; Yang, D.; Li, W.; Wang, B.; Jiang, Z.; Li, M. Antiviral Activity of Recombinant Mouse $\beta$-Defensin 3 against Influenza A Virus in Vitro and in Vivo. Antivir. Chem. Chemother. 2012, 22, 255-262. [CrossRef]

43. Park, M.S.; Kim, J.I.; Lee, I.; Park, S.; Bae, J.-Y.; Park, M.-S. Towards the Application of Human Defensins as Antivirals. Biomol. Ther. 2018, 26, 242-254. [CrossRef]

44. Zhao, H.; To, K.K.W.; Sze, K.-H.; Yung, T.T.-M.; Bian, M.; Lam, H.; Yeung, M.L.; Li, C.; Chu, H.; Yuen, K.-Y. A Broad-Spectrum Virus- and Host-Targeting Peptide against Respiratory Viruses Including Influenza Virus and SARS-CoV-2. Nat. Commun. 2020, 11, 4252. [CrossRef]

45. Zhao, H.; To, K.K.W.; Chu, H.; Ding, Q.; Zhao, X.; Li, C.; Shuai, H.; Yuan, S.; Zhou, J.; Kok, K.-H.; et al. Dual-Functional Peptide with Defective Interfering Genes Effectively Protects Mice against Avian and Seasonal Influenza. Nat. Commun. 2018, 9, 2358. [CrossRef]

46. Yu, Y.; Deng, Y.-Q.; Zou, P.; Wang, Q.; Dai, Y.; Yu, F.; Du, L.; Zhang, N.-N.; Tian, M.; Hao, J.-N.; et al. A Peptide-Based Viral Inactivator Inhibits Zika Virus Infection in Pregnant Mice and Fetuses. Nat. Commun. 2017, 8, 15672. [CrossRef]

47. Lu, L.; Liu, Q.; Zhu, Y.; Chan, K.-H.; Qin, L.; Li, Y.; Wang, Q.; Chan, J.F.-W.; Du, L.; Yu, F.; et al. Structure-Based Discovery of Middle East Respiratory Syndrome Coronavirus Fusion Inhibitor. Nat. Commun. 2014, 5, 3067. [CrossRef]

48. Li, Q.; Zhao, Z.; Zhou, D.; Chen, Y.; Hong, W.; Cao, L.; Yang, J.; Zhang, Y.; Shi, W.; Cao, Z.; et al. Virucidal Activity of a Scorpion Venom Peptide Variant Mucroporin-M1 against Measles, SARS-CoV and Influenza H5N1 Viruses. Peptides 2011, 32, 1518-1525. [CrossRef]

49. Liu, S.; Lu, H.; Niu, J.; Xu, Y.; Wu, S.; Jiang, S. Different from the HIV Fusion Inhibitor C34, the Anti-HIV Drug Fuzeon (T-20) Inhibits HIV-1 Entry by Targeting Multiple Sites in Gp41 and Gp120. J. Biol. Chem. 2005, 280, 11259-11273. [CrossRef]

50. Gomes, B.; Augusto, M.T.; Felício, M.R.; Hollmann, A.; Franco, O.L.; Gonçalves, S.; Santos, N.C. Designing Improved Active Peptides for Therapeutic Approaches against Infectious Diseases. Biotechnol. Adv. 2018, 36, 415-429. [CrossRef]

51. Kelley, L.A.; Mezulis, S.; Yates, C.M.; Wass, M.N.; Sternberg, M.J.E. The Phyre2 Web Portal for Protein Modeling, Prediction and Analysis. Nat. Protoc. 2015, 10, 845-858. [CrossRef]

52. Xia, S.; Yan, L.; Xu, W.; Agrawal, A.S.; Algaissi, A.; Tseng, C.-T.K.; Wang, Q.; Du, L.; Tan, W.; Wilson, I.A.; et al. A Pan-Coronavirus Fusion Inhibitor Targeting the HR1 Domain of Human Coronavirus Spike. Sci. Adv. 2019, 5, eaav4580. [CrossRef] [PubMed]

53. Xia, S.; Zhu, Y.; Liu, M.; Lan, Q.; Xu, W.; Wu, Y.; Ying, T.; Liu, S.; Shi, Z.; Jiang, S.; et al. Fusion Mechanism of 2019-NCoV and Fusion Inhibitors Targeting HR1 Domain in Spike Protein. Cell. Mol. Immunol. 2020, 17, 765-767. [CrossRef]

54. Zhao, H.; Zhou, J.; Zhang, K.; Chu, H.; Liu, D.; Poon, V.K.-M.; Chan, C.C.-S.; Leung, H.-C.; Fai, N.; Lin, Y.-P.; et al. A Novel Peptide with Potent and Broad-Spectrum Antiviral Activities against Multiple Respiratory Viruses. Sci. Rep. 2016, 6, 22008. [CrossRef]

55. Wang, C.; Wang, S.; Li, D.; Wei, D.-Q.; Zhao, J.; Wang, J. Human Intestinal Defensin 5 Inhibits SARS-CoV-2 Invasion by Cloaking ACE2. Gastroenterology 2020, 159, 1145-1147. [CrossRef] [PubMed] 
56. Mahendran, A.S.K.; Lim, Y.S.; Fang, C.-M.; Loh, H.-S.; Le, C.F. The Potential of Antiviral Peptides as COVID-19 Therapeutics. Front. Pharmacol. 2020, 11. [CrossRef]

57. Daly, N.L.; Chen, Y.-K.; Rosengren, K.J.; Marx, U.C.; Phillips, M.L.; Waring, A.J.; Wang, W.; Lehrer, R.I.; Craik, D.J. Retrocyclin-2: Structural Analysis of a Potent Anti-HIV Theta-Defensin. Biochemistry 2007, 46, 9920-9928. [CrossRef]

58. Sample, C.J.; Hudak, K.E.; Barefoot, B.E.; Koci, M.D.; Wanyonyi, M.S.; Abraham, S.; Staats, H.F.; Ramsburg, E.A. A MastoparanDerived Peptide Has Broad-Spectrum Antiviral Activity against Enveloped Viruses. Peptides 2013, 48, 96-105. [CrossRef]

59. Talactac, M.R.; Yada, Y.; Yoshii, K.; Hernandez, E.P.; Kusakisako, K.; Maeda, H.; Galay, R.L.; Fujisaki, K.; Mochizuki, M.; Tanaka, T. Characterization and Antiviral Activity of a Newly Identified Defensin-like Peptide, HEdefensin, in the Hard Tick Haemaphysalis Longicornis. Dev. Comp. Immunol. 2017, 68, 98-107. [CrossRef]

60. Talactac, M.R.; Yoshii, K.; Maeda, H.; Kusakisako, K.; Hernandez, E.P.; Tsuji, N.; Fujisaki, K.; Galay, R.L.; Tanaka, T.; Mochizuki, M. Virucidal Activity of Haemaphysalis longicornis Longicin P4 Peptide against Tick-Borne Encephalitis Virus Surrogate Langat Virus. Parasit. Vectors 2016, 9, 59. [CrossRef] [PubMed]

61. Li, F.; Lang, Y.; Ji, Z.; Xia, Z.; Han, Y.; Cheng, Y.; Liu, G.; Sun, F.; Zhao, Y.; Gao, M.; et al. A Scorpion Venom Peptide Ev37 Restricts Viral Late Entry by Alkalizing Acidic Organelles. J. Biol. Chem. 2019, 294, 182-194. [CrossRef]

62. Swanson, M.D.; Boudreaux, D.M.; Salmon, L.; Chugh, J.; Winter, H.C.; Meagher, J.L.; André, S.; Murphy, P.V.; Oscarson, S.; Roy, R.; et al. Engineering a Therapeutic Lectin by Uncoupling Mitogenicity from Antiviral Activity. Cell 2015, 163, 746-758. [CrossRef]

63. Nguyen, G.K.T.; Lim, W.H.; Nguyen, P.Q.T.; Tam, J.P. Novel Cyclotides and Uncyclotides with Highly Shortened Precursors from Chassalia chartacea and Effects of Methionine Oxidation on Bioactivities. J. Biol. Chem. 2012, 287, 17598-17607. [CrossRef]

64. Ngai, P.H.K.; Ng, T.B. Coccinin, an Antifungal Peptide with Antiproliferative and HIV-1 Reverse Transcriptase Inhibitory Activities from Large Scarlet Runner Beans. Peptides 2004, 25, 2063-2068. [CrossRef]

65. Hallock, Y.F.; Sowder, R.C.; Pannell, L.K.; Hughes, C.B.; Johnson, D.G.; Gulakowski, R.; Cardellina, J.H.; Boyd, M.R. Cycloviolins A-D, Anti-HIV Macrocyclic Peptides from Leonia cymosa. J. Org. Chem. 2000, 65, 124-128. [CrossRef]

66. Rozek, T.; Waugh, R.J.; Steinborner, S.T.; Bowie, J.H.; Tyler, M.J.; Wallace, J.C. The Maculatin Peptides from the Skin Glands of the Tree Frog Litoria genimaculata: A Comparison of the Structures and Antibacterial Activities of Maculatin 1.1 and Caerin 1.1. J. Pept. Sci. 1998, 4, 111-115. [CrossRef]

67. Stone, D.J.M.; Waugh, R.J.; Bowie, J.H.; Wallace, J.C.; Tyler, M.J. Peptides from Australian Frogs. Structures of the Caerins and Caeridin 1 from Litoria splendida. J. Chem. Soc. Perkin Trans. 1992, 3173-3178. [CrossRef]

68. Holthausen, D.J.; Lee, S.H.; Kumar, V.T.; Bouvier, N.M.; Krammer, F.; Ellebedy, A.H.; Wrammert, J.; Lowen, A.C.; George, S.; Pillai, M.R.; et al. An Amphibian Host Defense Peptide Is Virucidal for Human H1 Hemagglutinin-Bearing Influenza Viruses. Immunity 2017, 46, 587-595. [CrossRef]

69. Murakami, T.; Niwa, M.; Tokunaga, F.; Miyata, T.; Iwanaga, S. Direct Virus Inactivation of Tachyplesin I and Its Isopeptides from Horseshoe Crab Hemocytes. Chemotherapy 1991, 37, 327-334. [CrossRef]

70. Boyd, M.R.; Gustafson, K.R.; McMahon, J.B.; Shoemaker, R.H.; O'Keefe, B.R.; Mori, T.; Gulakowski, R.J.; Wu, L.; Rivera, M.I.; Laurencot, C.M.; et al. Discovery of Cyanovirin-N, a Novel Human Immunodeficiency Virus-Inactivating Protein That Binds Viral Surface Envelope Glycoprotein Gp120: Potential Applications to Microbicide Development. Antimicrob. Agents Chemother. 1997, 41, 1521-1530. [CrossRef] [PubMed]

71. Moon, H.-J.; Nikapitiya, C.; Lee, H.-C.; Park, M.-E.; Kim, J.-H.; Kim, T.-H.; Yoon, J.-E.; Cho, W.-K.; Ma, J.Y.; Kim, C.-J.; et al. Inhibition of Highly Pathogenic Avian Influenza (HPAI) Virus by a Peptide Derived from VFLIP through Its Direct Destabilization of Viruses. Sci. Rep. 2017, 7, 4875. [CrossRef]

72. Hussain, M.; Galvin, H.D.; Haw, T.Y.; Nutsford, A.N.; Husain, M. Drug Resistance in Influenza A Virus: The Epidemiology and Management. Infect. Drug Resist. 2017, 10, 121-134. [CrossRef] [PubMed]

73. Pillay, D.; Zambon, M. Antiviral Drug Resistance. BMJ 1998, 317, 660-662. [CrossRef] [PubMed]

74. Chang, K.Y.; Yang, J.-R. Analysis and Prediction of Highly Effective Antiviral Peptides Based on Random Forests. PLoS ONE 2013, 8, e70166. [CrossRef] [PubMed]

75. Feng, J.Y.; Murakami, E.; Zorca, S.M.; Johnson, A.A.; Johnson, K.A.; Schinazi, R.F.; Furman, P.A.; Anderson, K.S. Relationship between Antiviral Activity and Host Toxicity: Comparison of the Incorporation Efficiencies of 2', $3^{\prime}$-Dideoxy-5-Fluoro-3' Thiacytidine-Triphosphate Analogs by Human Immunodeficiency Virus Type 1 Reverse Transcriptase and Human Mitochondrial DNA Polymerase. Antimicrob. Agents Chemother. 2004, 48, 1300-1306. [CrossRef] [PubMed]

76. Carr, A. Toxicity of Antiretroviral Therapy and Implications for Drug Development. Nat. Rev. Drug Discov. 2003, 2, 624-634. [CrossRef] [PubMed]

77. Sala, A.; Ardizzoni, A.; Ciociola, T.; Magliani, W.; Conti, S.; Blasi, E.; Cermelli, C. Antiviral Activity of Synthetic Peptides Derived from Physiological Proteins. Intervirology 2018, 61, 166-173. [CrossRef] [PubMed]

78. Agarwal, G.; Gabrani, R. Antiviral Peptides: Identification and Validation. Int. J. Pept. Res. Ther. 2020, 1-20. [CrossRef] [PubMed]

79. Yuan, L.; Zhang, S.; Peng, J.; Li, Y.; Yang, Q. Synthetic Surfactin Analogues Have Improved Anti-PEDV Properties. PLoS ONE 2019, 14, e0215227. [CrossRef] [PubMed]

80. Vilas Boas, L.C.P.; Campos, M.L.; Berlanda, R.L.A.; de Carvalho Neves, N.; Franco, O.L. Antiviral Peptides as Promising Therapeutic Drugs. Cell. Mol. Life Sci. CMLS 2019, 76, 3525-3542. [CrossRef]

81. Di, L. Strategic Approaches to Optimizing Peptide ADME Properties. AAPS J. 2015, 17, 134-143. [CrossRef] [PubMed] 
82. Shartouny, J.R.; Jacob, J. Mining the Tree of Life: Host Defense Peptides as Antiviral Therapeutics. Semin. Cell Dev. Biol. 2019, 88, 147-155. [CrossRef] [PubMed]

83. Pattabiraman, V.R.; Bode, J.W. Rethinking Amide Bond Synthesis. Nature 2011, 480, 471-479. [CrossRef] [PubMed]

84. McGregor, D.P. Discovering and Improving Novel Peptide Therapeutics. Curr. Opin. Pharmacol. 2008, 8, 616-619. [CrossRef] [PubMed] 